\title{
Study to monitor the adverse effects by different HAART regimens in HIV patients with tuberculosis
}

\author{
Radhey Shyam ${ }^{1}$, Arpita Singh ${ }^{2} *$, Dheeraj Kumar Singh ${ }^{3}$, Ajay Kumar Verma ${ }^{4}$, \\ Pratap Shankar ${ }^{3}$, Sachin Tutu ${ }^{3}$, Rakesh Kumar Dixit ${ }^{3}$
}

\begin{abstract}
${ }^{1}$ Department of Tuberculosis and Respiratory Diseases, GSVM Medical College, Kanpur, Uttar Pradesh, India ${ }^{2}$ Department of Pharmacology, GMC, Kannauj, Uttar Pradesh, India

${ }^{3}$ Department of Pharmacology and Therapeutics, King George's Medical University, Lucknow, Uttar Pradesh, India ${ }^{4}$ Department of Respiratory Medicine, King George's Medical University, Lucknow, Uttar Pradesh, India
\end{abstract}

Received: 17 October 2016 Accepted: 17 November 2016

\section{*Correspondence to:}

Dr. Arpita Singh,

Email: drarpitasingh21@gmail.com

Copyright: (c) the author(s), publisher and licensee Medip Academy. This is an openaccess article distributed under the terms of the Creative Commons Attribution NonCommercial License, which permits unrestricted noncommercial use, distribution, and reproduction in any medium, provided the original work is properly cited.

\begin{abstract}
Background: In the modern era, AIDS is not less than a disaster for the human race. More than two-third of HIV-infected individuals have an associated infectious pulmonary disease. Mycobacterium tuberculosis is more virulent than most of other opportunistic pathogen causing latent infection. HIV is characterized by a profound immunodeficiency resulting from a progressive, quantitative and qualitative deficiency of the subset of CD4 T lymphocytes referred to as helper $\mathrm{T}$ cells leading to the patient at high risk of developing a variety of opportunistic infections. At present AIDS is incurable but some of the drugs have shown to decrease the mortality and morbidity of the disease. These are called as Highly Active Anti-Retroviral Therapy (HAART). However, these drugs are associated with a significant number of side effects. This work has been conducted in order to study the demographic profile of HIV patients with TB and monitor the adverse effects of different HAART regimens among them. Methods: A total of 3078 patients screened for the study. Those who were diagnosed with HIV were enrolled. Pretreatment parameters like, CD4, CD8 + lymphocyte count and their ratio, haemogram etc. were recorded. Patients were divided into four groups and were started with different HAART regimens. They were monitored regularly for the appearance of any adverse effects.

Results: The prevalence of HIV sero-positivity was found to be $3.60 \%$. Out of them, $71.18 \%$ were males and $28.82 \%$ were females. The highest prevalence $(43.29 \%)$ was in the age group of 21-50 years. The sero-positive rate was found more in married males as compared to married females and unmarried cases. Side effects were present in all the groups. The most common side effect was GI intolerance and was most frequent in Group I. Anemia and neutropenia occurred in the Zidovudine containing groups (group I, III and IV). Peripheral neuropathy occurred most commonly in cases of Group II. Rashes occurred in nevirapine containing groups. Liver function derangement was noticed more in group I and II. $71.4 \%$ of patients on HAART regimen showed improvement in symptoms while $28.57 \%$ did not show any improvement.

Conclusions: The prevalence of HIV sero-positivity in our study was $3.60 \%$. The rate of sero-positivity was more in males as compared to females while it was highest in the individuals of 21-50 years of age. The most common side effect was GI intolerance and was most frequent in Group I. Anemia and neutropenia occurred most frequently in Zidovudine containing groups. Peripheral neuropathy occurred most commonly in cases of Group II (Stavudine + Lamivudine + Nevirapine). Deranged lipid profile was found to occur due to indinavir in patients of Group IV. After starting on HAART regimens, 74.4\% showed significant improvement in symptoms.
\end{abstract}

Keywords: Antiretroviral regimens, AIDS, CD4 count, HAART, Seropositive

\section{INTRODUCTION}

AIDS, the Acquired Immuno Deficiency Syndrome, is a modern pandemic. ${ }^{1}$ The disease has become a disaster for the human race in the present era. According to studies, 
more than two- third of HIV infected individuals have an associated infectious pulmonary disease. Mycobacterium tuberculosis is more virulent than most of other opportunistic pathogen causing latent infection and hence, is often first endogenous infection to reactivate CD4 lymphocyte and macrophages dysfunction in HIV patient placing them at a high risk for both primary and reactivation tuberculosis. ${ }^{2}$ The initial phase of the disease is known as sero conversion illness. The next phase is known as asymptomatic HIV infections or AIDS-related complex. $^{3}$

AIDS is characterized by immunodeficiency resulting from a progressive and quantitative and qualitative deficiency of the subset of CD4 T lymphocytes referred to as helper $\mathrm{T}$ cells leading to the patient at high risk of developing a variety of opportunistic infections. ${ }^{4}$ Cure of AIDS is still a query but some of the drugs have been evolved to decrease the mortality and morbidity of the disease. These are called as Highly Active AntiRetroviral Therapy (HAART). ${ }^{5}$

HAART works by suppression of viral load and restoring the immune system. ${ }^{6}$ Despite these advantages, adverse reactions due to these drugs are a matter of concern and may affect the effectiveness of the ART programmes. The risk arises because of the effect of the disease on the immune systems as well as due to the safety profiles of the ART drugs. There are a number of ADRs related to HAART that have been reported. It may range from mild to severe and short to long term depending on the environment. ${ }^{7-9}$ ADRs in developing nations can differ from those in developed nations. Apart from the environment and the type of ART regimen, a number of other risk factors have been identified, that include patient age, gender, body mass index (BMI), duration of treatment, biomarkers of disease such as CD4 count and viral load. ${ }^{10,11}$ This work has been conducted in order to monitor the adverse effect by different HAART regimens in HIV patients with Tuberculosis.

\section{METHODS}

The study was started after the approval from Institutional Ethics Committee. All the patients were recruited after filling the Informed Consent Form.

\section{Study population}

A total of 3078 patients screened for the study. Patients were taken from:

- Those attending out-patient department and admitted as indoor patients in the department of Tuberculosis and Respiratory diseases.

- High-risk patients from Obstetrics and Gynecology, Skin and VD, Pathology and Blood Bank.

Study was conducted over a period of 18 months.

\section{Lab studies}

HIV positive patients were subjected to following tests:

- Sputum smear for AFB

- Haemogram

- PPD skin test

- $\mathrm{X}$ - ray chest, PA view

- CD4, CD8 + lymphocyte count and their ratio

- Urine examination- Routine and Microscopic

- Immonocomb Assay test for HIV in all admitted cases and in cases which were highly suspicious having AIDS by clinical features.

- ELISA test of HIV in those who were positive immunocomb or immunocomb negative but with highly suspicious clinical features.

\section{Antiretroviral therapy}

Different groups of patients (Table 1) were prescribed different ART regimens according to following criteria:

- Clinical presentations

- H/O contact to commercial sex workers, drug abuse and blood transfusion

- Immunocomb positive status

- ELISA positive status

- Either CD4 count less than 200cells/ $\mu 1$ or patients with AIDS defining illness (WHO Guidelines)

Statistical analysis was done using SPSS Software. pvalue $<0.05$ was considered significant.

Table 1: Different groups of patients prescribed with different ART regimens.

\begin{tabular}{|c|c|c|c|}
\hline Group I & Group II & Group III & Group IV \\
\hline 2 NRTI + 1 NNRTI & 2NRTI + 1NNRTI & 2NRTI + 1NNRTI & 2NRTI + 1PI \\
\hline Zidovudine (300 mg bid) & Stavudine (40 mg bid) & & \multirow{7}{*}{$\begin{array}{l}\text { Zidovudine (300 mg bid) } \\
\quad+ \\
\text { Lamivudine (150 mg bid; } \\
\text { 2mg/kg if body wt. }<50 \mathrm{~kg} \\
\quad+ \\
\text { Indinavir (800 mg TDS) }\end{array}$} \\
\hline+ & + & Zidovudine (300 mg bid) & \\
\hline Lamivudine (150 mg bid; & Lamivudine (150 mg bid; & + & \\
\hline $\begin{array}{l}2 \mathrm{mg} / \mathrm{kg} \text { if body wt. }<50 \mathrm{~kg} \text { ) } \\
+\end{array}$ & $2 \mathrm{mg} / \mathrm{kg}$ if body wt. $<50 \mathrm{~kg}$ ) & $\begin{array}{l}\text { Lamivudine }(150 \mathrm{mg} \text { bid; } \\
2 \mathrm{mg} / \mathrm{kg} \text { if body wt. }<50\end{array}$ & \\
\hline Nevirapine (200 mg OD for & Nevirapine (200 mg OD for & & \\
\hline 14 days, then $200 \mathrm{mg}$ bid for & 14 days, then $200 \mathrm{mg}$ bid for & + & \\
\hline $\begin{array}{l}14 \text { days; } 4 \mathrm{mg} / \mathrm{kg} \text { for } 14 \text { days } \\
\text { then twice daily for children) }\end{array}$ & $\begin{array}{l}14 \text { days; } 4 \mathrm{mg} / \mathrm{kg} \text { for } 14 \text { days } \\
\text { then twice daily for children) }\end{array}$ & Efavirenz (600 mg OD) & \\
\hline
\end{tabular}




\section{RESULTS}

Results are shown in form of age and sex wise distribution of the study population (both HIV positive and HIV negative) (Table 2), HIV sero-positivity in total screened cases (Table 3), HIV sero-positive according to age and sex of the patient (Table 4), marital status of HIV sero-positivs excluding 2 children (Table 5), educational status of HIV sero-positives (Table 6), radiological presentation in HIV sero-positives with pulmonary tuberculosis (72 cases) (Table 7), age wise distribution of patients who received antiretroviral therapy (Table 8), baseline $\mathrm{CD} 4+\mathrm{t}$ lymphocyte count in patient at the time of starting art, symptomatic trend in patients on HAART (Table 9), comparison of side effects of HAART (Table $10)$.

Table 2: Age and sex wise distribution of the study population (both HIV positive and HIV negative).

\begin{tabular}{|llll|}
\hline $\begin{array}{l}\text { Age group } \\
(\text { yrs })\end{array}$ & Male (\%) & Male (\%) & Total $(\%)$ \\
\hline$<10$ & $38(64.4)$ & $21(35.6)$ & $59(1.9)$ \\
\hline $11-20$ & $81(51.9)$ & $75(48.1)$ & $156(5.1)$ \\
\hline $21-30$ & $668(69.4)$ & $295(30.6)$ & $963(31.3)$ \\
\hline $31-40$ & $692(66.9)$ & $342(33.1)$ & $1034(33.6)$ \\
\hline $41-50$ & $274(60.9)$ & $176(39.1)$ & $450(14.6)$ \\
\hline $51-60$ & $178(74.1)$ & $62(25.9)$ & $240(7.8)$ \\
\hline$>60$ & $108(61.4)$ & $68(38.6)$ & $176(5.7)$ \\
\hline Total & $2039(66.2)$ & $1039(33.8)$ & $3078(100)$ \\
\hline
\end{tabular}

Table 3: HIV Sero-positivity in total screened cases.

\begin{tabular}{|llll|}
\hline Sex & $\begin{array}{l}\text { No. of patients } \\
(\%)\end{array}$ & $\begin{array}{l}\text { HIV sero- } \\
\text { positivite }(\%)\end{array}$ & $\begin{array}{l}\text { HIV sero- } \\
\text { negative }(\%)\end{array}$ \\
\hline Male & $2039(66.2)$ & $79(3.874)$ & $1960(96.12)$ \\
\hline Female & $1039(33.8)$ & $32(3.079)$ & $1007(96.92)$ \\
\hline Total & $3078(100)$ & $111(3.60)$ & $2967(96.39)$ \\
\hline
\end{tabular}

Table 4: HIV sero-positive according to age and sex of the patient.

\begin{tabular}{|llll|}
\hline $\begin{array}{l}\text { Age } \\
\text { group } \\
(\text { yrs })\end{array}$ & $\begin{array}{l}\text { HIV sero- } \\
\text { positive } \\
\text { male }(\%)\end{array}$ & $\begin{array}{l}\text { HIV sero- } \\
\text { positive } \\
\text { male }(\%)\end{array}$ & $\begin{array}{l}\text { No. of } \\
\text { cases }(\%)\end{array}$ \\
\hline$<10$ & $2(1.80)$ & - & $2(1.80)$ \\
\hline $11-20$ & $5(4.50)$ & $2(1.8)$ & $7(6.30)$ \\
\hline $21-30$ & $25(22.52)$ & $14(12.61)$ & $39(35.13)$ \\
\hline $31-40$ & $35(31.53)$ & $13(11.71)$ & $48(43.24)$ \\
\hline $41-50$ & $9(8.10)$ & $2(1.8)$ & $11(9.9)$ \\
\hline$>50$ & $3(2.70)$ & $1(0.90)$ & $4(3.6)$ \\
\hline Total & $35(71.17)$ & $32(28.82)$ & $11(100)$ \\
\hline
\end{tabular}

Table 5: Marital status of HIV sero-positives excluding 2 children.

\begin{tabular}{|lll|l|}
\hline Marital status & Male & Female & Total \\
\hline Married & $56(72.72)$ & $30(93.75)$ & $86(78.89)$ \\
\hline Unmarried & $18(23.37)$ & - & $18(16.51)$ \\
\hline $\begin{array}{l}\text { Widow/widower/ } \\
\text { divorcee }\end{array}$ & $3(3.89)$ & $2(6.25)$ & $5(4.58)$ \\
\hline Total & $77(100)$ & $32(100)$ & $109(100)$ \\
\hline
\end{tabular}

Table 6: Educational status of HIV sero-positives.

\begin{tabular}{|llll|}
\hline Educational status & $\begin{array}{l}\text { No. of cases } \\
\text { Male } \\
(\mathbf{\%})\end{array}$ & $\begin{array}{l}\text { Female } \\
(\mathbf{\%})\end{array}$ & $\begin{array}{l}\text { Total } \\
(\mathbf{\%})\end{array}$ \\
\hline Illiterate & 13 & 15 & $28(25.2)$ \\
\hline Upto primary school & 14 & 4 & $18(16.2)$ \\
\hline Upto X class & 33 & 10 & $43(38.7)$ \\
\hline Upto XII class & 10 & - & $10(9.0)$ \\
\hline Graduate/ post- graduate & 9 & 3 & $12(10.8)$ \\
\hline Total & 79 & 32 & $111(100)$ \\
\hline
\end{tabular}

Table 7: Radiological presentation in HIV seropositives with pulmonary tuberculosis (72 cases).

\begin{tabular}{|c|c|c|c|c|}
\hline $\begin{array}{l}\text { Zone } \\
\text { involved }\end{array}$ & $\begin{array}{l}\text { Right } \\
\text { lung field }\end{array}$ & $\begin{array}{l}\text { Left lung } \\
\text { field }\end{array}$ & Bilateral & Total (\%) \\
\hline Upper & 3 & 1 & 1 & $\begin{array}{l}5 \\
(8.06 \%)\end{array}$ \\
\hline Middle & 3 & 1 & 5 & $9(14.51 \%)$ \\
\hline Lower & 5 & 1 & 3 & $\begin{array}{l}9 \\
(14.51 \%)\end{array}$ \\
\hline Multiple & 11 & 1 & 27 & $\begin{array}{l}39 \\
(62.90 \%)\end{array}$ \\
\hline Total & $\begin{array}{l}2 \\
(3.22 \%)\end{array}$ & $\begin{array}{l}4 \\
(6.45 \%)\end{array}$ & $\begin{array}{l}6 \\
58.06 \%)\end{array}$ & $\begin{array}{l}62 \\
(100 \%)\end{array}$ \\
\hline
\end{tabular}

Table 8: Age wise distribution of patients who received antiretroviral therapy.

\begin{tabular}{|llll|}
\hline Age groups (yrs) & Male & Female & Total (\%) \\
\hline$<10$ & 1 & 0 & $1(1.66)$ \\
\hline $11-20$ & 1 & 0 & $1(1.66)$ \\
\hline $21-30$ & 10 & 9 & $19(31.66)$ \\
\hline $31-40$ & 21 & 6 & $27(45)$ \\
\hline $41-50$ & 7 & 3 & $10(16.66)$ \\
\hline$>50$ & 2 & 0 & $2(3.33)$ \\
\hline Total & $42(70 \%)$ & $18(30 \%)$ & $60(100)$ \\
\hline
\end{tabular}

Table 9: Symptomatic trend in patients on HAART.

\begin{tabular}{|ll|}
\hline Improvement & Non improvement \\
\hline $30(71.4 \%)$ & $12(28.57 \%)$ \\
\hline
\end{tabular}


Table 10: Comparison of side effects with HAART.

\begin{tabular}{|c|c|c|c|c|}
\hline Side effects & $\begin{array}{l}\text { Group } \\
\text { I }\end{array}$ & $\begin{array}{l}\text { Group } \\
\text { II }\end{array}$ & $\begin{array}{l}\text { Group } \\
\text { II }\end{array}$ & $\begin{array}{l}\text { Group } \\
\text { IV }\end{array}$ \\
\hline $\begin{array}{l}\text { Nausea, } \\
\text { vomiting }\end{array}$ & 8 & $\begin{array}{l}1 \\
(8 \%)\end{array}$ & $\begin{array}{l}2 \\
(25 \%)\end{array}$ & - \\
\hline $\begin{array}{l}\text { Anemia, } \\
\text { neutropenia }\end{array}$ & 3 & - & 2 & $\begin{array}{l}1 \\
(16 \%)\end{array}$ \\
\hline Skin rases & 2 & $\begin{array}{l}3 \\
(25 \%)\end{array}$ & $\begin{array}{l}1 \\
(12.5 \%)\end{array}$ & - \\
\hline $\begin{array}{l}\text { Peripheral } \\
\text { neuropathy }\end{array}$ & & $\begin{array}{l}1 \\
(8 \%)\end{array}$ & - & - \\
\hline $\begin{array}{l}\text { Elevated serum } \\
\text { aminotransferase } \\
\text { levels }\end{array}$ & 2 & $\begin{array}{l}1 \\
(8 \%)\end{array}$ & $\begin{array}{l}1 \\
(12.5 \%)\end{array}$ & - \\
\hline Hepatitis & 3 & $\begin{array}{l}2 \\
(16 \%)\end{array}$ & - & $\begin{array}{l}1 \\
(16 \%)\end{array}$ \\
\hline $\begin{array}{l}\text { Deranged lipid } \\
\text { profile }\end{array}$ & - & - & - & $\begin{array}{l}1 \\
(16 \%)\end{array}$ \\
\hline
\end{tabular}

\section{DISCUSSION}

In the present study the prevalence of HIV sero-positivity was found to be $3.60 \%$. Studies conducted by Sivaraman and Arora showed it to be $2.7 \%$ and $3.4 \%$ respectively. ${ }^{12,13}$ Out of 111 seropositive cases, $71.18 \%$ were males and $28.82 \%$ were females. Seroprevalence of HIV infection in males was $3.87 \%$ while in females it was $3.07 \%$. According to Mohanty et al, out of total seropositive cases $66.25 \%$ were males and $33.75 \%$ were females. ${ }^{14}$ The highest prevalence $(43.29 \%)$ was in the age group of 21-50 years same as Mohanty et al. ${ }^{10}$ The sero-positive rate was found more in married males as compared to married females and unmarried cases. The incidence was higher in those having matriculate level of education and it decreased in those having higher level of education.

In our study most common diagnosis among the seropositive cases was of Tuberculosis with $72.07 \%$ cases. According to the radiological presentation in seropositive HIV with pulmonary TB, multiple zonal involvements were found in $62.9 \%$ of cases. Bilateral involvement of lungs was found in $58.06 \%$ of seropositive cases.

Out of 111 seropositive cases, 60 received HAART. Most of them $(45 \%)$ were in the age group $21-40$ years. Mean age was $33.52 \pm 8.68$. Out of total 60 patients only 42 revisited for follow up. They were further divided into 4 groups and started with different HAART regimens and monitored for development of any adverse effects.

Side effects were present in all the groups. The most common side effect was GI intolerance and was most frequent in Group I. Anemia and neutropenia occurred in Zidovudine containing groups (group I, III and IV). Peripheral neuropathy occurred most commonly in cases of Group II. Rashes occurred due to nevirapine in 2 patients of Group I and 3 patients of Group III. Liver function derangement was noticed in 10 patients $(5,3,1$, 1 respectively in group I, II, III, and IV).

Among the patients who were put on HAART, $71.4 \%$ showed improvement in symptoms while $28.57 \%$ did not show any improvement.

\section{CONCLUSION}

Out of 3078 patients attending pulmonary medicine department and screened for HIV, 111 (3.60\%) were HIV positive by ELISA method. Out of them, $71.17 \%$ were males and $28.82 \%$ were females. Most of them $(78.3 \%)$ were in the age group of $21-40$ years. $72.07 \%$ of HIV seropositive cases were of tuberculosis. A total of 60 patients were started on HAART. Only 42 of them agreed to re-visit for follow-up.

The most common side effect was GI intolerance and was most frequent in Group I. Anemia and neutropenia occurred most frequently in Zidovudine containing groups. Peripheral neuropathy occurred most commonly in cases of Group II. Deranged lipid profile was found to occur due to indinavir in patients of Group IV. $74.4 \%$ of the cases on HAART showed significant improvement in symptoms.

\section{ACKNOWLEDGMENT}

I am very much grateful to my Head of Department Prof. K. K. Pant for his kind cooperation and immense support.

Funding: No funding sources

Conflict of interest: None declared

Ethical approval: The study was approved by the Institutional Ethics Committee

\section{REFERENCES}

1. AIDS 2002: Antiretroviral Therapy guidelines. File Format PDF, Adobe Acrobat- View as HTML from the Internet at http://www.aidsinfonet.org New Mexico AIDS Infonet www.aidsinfonet.org Fact Sheet Number 4112002 ANTIRETROVIRAL THERAPY GUIDELINES www.aids.org/411guidelines.

2. Arora VK, Seethaaraman ML, Gowrinath K, Rao SR. lung and HIV infectio with special reference to tuberculosis Indian Chest Dis. Allied Science. 1993;35(3):103-12.

3. Dhurat R, Manglanu M, Sharma R, Shah NK. Clinical spectrum of HIV infection Indian Pediatr. 2000 Aug;37(8):831-6.

4. Merchant RH, Oswal JS, Bhagwat RV, Karkare J. clinical profile of HIV infection Indian Pediatr. 2001 Mar;38(3):239-46.

5. Oka S. current HIV therapy and its clinical problems. Rinsho Byori. 2000 Jul;48(7):575-9. 
6. Mehta U. Pharmacovigilance: the devastating consequences of not thinking about adverse drug reactions. Contin Med Educ. 2011;29(6):247-2251.

7. Shubber Z, Calmy A, Andrieux-Meyer I, Vitoria M, Renaud Thery F, Shaffer N, et al. Adverse events associated with nevirapine and efavirenz-based firstline antiretroviral therapy: a systematic review and meta-analysis. AIDS. 2013;27:1403-12.

8. Reddenna L, Basha SA, Gopal DV, Krishna TR. Highly Active antiretroviral Therapy: Incidence of Adverse Drug Reactions. International Journal of Allied Medicinal Sciences and Clinical Research. 2013(1):25-30.

9. Srikanth AB, Babu SC, Yadav HN, SK J. Incidence of adverse drug reactions in human immune deficiency virus-positive patients using highly active antiretroviral therapy. J Adv Pharm Technol Res. 2012;3:62-7.

10. Luma NH, Doualla MS, Choukem SP, Temfack E, Ashuntantang G, Joko HA, et al. Adverse drug reactions of Highly Active Antiretroviral Therapy (HAART) in HIV infected patients at the General
Hospital, Douala, Cameroon: A cross sectional study. Pan Afr Med J. 2012;12:87.

11. Eluwa GI, Badru T, Akpoigbe KJ. Adverse drug reactions to antiretroviral therapy (ARVs): incidence, type and risk factors in Nigeria. BMC Cen Clin Pharmacol. 2012;12:7.

12. Sivaraman V, Fernandez G, Rao SR. HIV infection in pulmonary TB. Report of six cases. Ind $\mathbf{J}$ Tuber. 1992;39:35-9.

13. Arora VK, Gowrinath K, Rao S. Extrapulmonary involvement in HIV with special reference to tuberculosis cases. Ind J Tub. 1995;42:27.

14. Mohanty KC, Basheer PMM. Changing trend of HIV infection and tuberculosis in a Bombay area since 1988. Indian J Tuberc. 1995;42:117-20.

Cite this article as: Shyam R, Singh A, Singh DK, Verma AK, Shankar P, Tutu S, et al. Study to monitor the adverse effects by different HAART regimens in HIV patients with tuberculosis. Int J Basic Clin Pharmacol 2017;6:108-12. 